\title{
GENETIC AND MORPHOLOGICAL VARIATION OF THE SOOTY-CAPPED BUSH TANAGER (CHLOROSPINGUS PILEATUS), A HIGHLAND ENDEMIC SPECIES FROM COSTA RICA AND WESTERN PANAMA
}

\author{
TANIA CHAVARRÍA-PIZARRO, ${ }^{1,2}$ GUSTAVO GUTIÉRREZ-ESPELETA, ${ }^{1}$ \\ ERIC J. FUCHS, ${ }^{1}$ AND GILBERT BARRANTES ${ }^{1}$
}

\begin{abstract}
We examined the effect of geographic isolation on morphology, genetic structure, and abundance of the Sooty-capped Bush Tanager (Chlorospingus pileatus), an endemic species restricted to highlands of Costa Rica and western Panama. Abundance and morphology were measured at five study sites and genetic variation was calculated from three microsatellite loci. We expected geographic discontinuities in this species' distribution to have an effect on its morphology and genetic structure. Genetic variation was higher within than between populations with no effect of geographic barriers on population genetic divergence in this species, indicating gene flow is high between populations. Unique alleles were detected in each population and $F_{s t}$ values increased with geographic distance between populations. Some morphological traits differed between populations, which may be caused by adaptation to different selective pressures in each population. Molecular data did not differ between the two color morphs that coexist in two isolated populations, which were considered different species. Received 16 July 2009. Accepted 22 November 2009.
\end{abstract}

Highland endemic avian species in the mountains of Costa Rica and western Panama currently show naturally isolated and discontinuous distributions, reflecting their confinement to mountain peaks and their isolation from other highland regions in the Neotropics (Stiles 1983; Barrantes 2000, 2009). Morphological and molecular divergence documented for some of these endemic highland species in Costa Rica correspond to this natural isolation (Stiles 1983, Barrantes 2000, Barrantes and Sánchez 2000). For example, isolated populations of the Volcano Hummingbird (Selasphorus flammula) and Fiery-throated Hummingbird (Panterpe insignis) differ in coloration and morphological dimensions (Stiles 1983, 1985). Similarly, geographic barriers have affected the genetic and morphological divergence among populations of the Black-and-yellow Phainoptila (Phainoptila melanoxantha) (Barrantes 2000, Barrantes and Sánchez 2000).

The Sooty-capped Bush Tanager (Chlorospingus pileatus) is endemic to the highlands of Costa Rica and western Panama. This species is naturally restricted to the summit of high mountains and primarily inhabits forest edges and open areas in the cloud forest and páramo. Sootycapped Bush Tanagers forage in flocks of 5-20 individuals, often accompanied by other small

\footnotetext{
${ }^{1}$ Escuela de Biología, Ciudad Universitaria Rodrigo Facio, Universidad de Costa Rica, San José, Costa Rica.

${ }^{2}$ Corresponding author;

e-mail: taniachavarria79@yahoo.com
}

birds (Powell 1985, Stiles and Skutch 1989). A grayish-green morph of Sooty-capped Bush Tanager (lighter morph) coexists on two high volcanoes (Irazú and Turrialba) of central Costa Rica with the darker and more widely distributed morph. The grayish-green morph was first considered a different species (Zeledon's Chlorospingus, Chlorospingus zeldoni) by Ridgway (1905), and Eisenmann (1955) and Slud (1964) continued $C$. zeledoni as a different species. However, Carriker (1910) suggested that $C$. zeledoni was a color morph of Sooty-capped Bush Tanager. Johnson and Brush (1972) analyzed the structure and pigment composition of feathers of both taxa and concluded C. zeledoni was a morph of Sooty-capped Bush Tanager. However, no further investigations have been conducted to test this hypothesis (e.g., using molecular data).

We used molecular data to analyze the effect of isolation (i.e., distance and barriers between populations) on genetic structure and morphology of the Sooty-capped Bush Tanager. We specifically hypothesized that small populations isolated by effective geographical barriers have a notable reduction in genetic variation. In addition, we searched for genetic differences between the two color morphs on Irazú volcano. To our knowledge, this is the first fine-scale genetic analysis, using microsatellites of an avian species endemic to the isolated highland regions of Costa Rica and western Panamá. Most species in this hotspot of diversity and endemism are restricted to a reduced portion of the highland forests and have low 


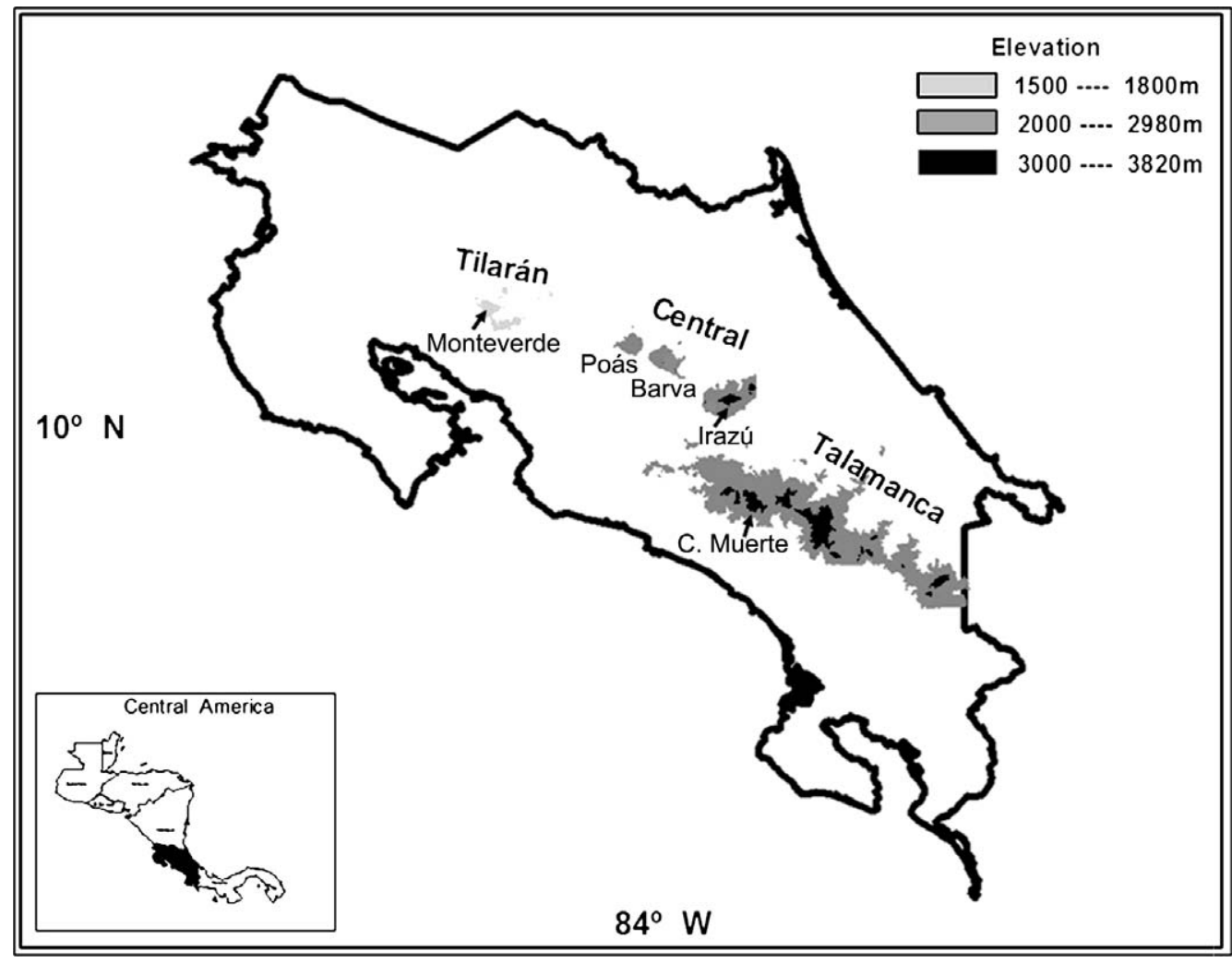

FIG. 1. Sampling localities in Costa Rican mountain ranges: Talamanca, Central Volcanic, and Tilarán. Locations of Monterverde, Irazú, and Cerro de la Muerte are indicated by black arrows.

abundance (Jankowski and Rabenold 2007, Barrantes 2009).

\section{METHODS}

Field Data Collection.-We conducted field work in highland forests of three Costa Rican mountain ranges: Talamanca Mountain Range, Central Mountain Range, and Tilarán Mountain Range (Fig. 1) from July 2003 through December 2005. Censuses and tissue collections were conducted at five different sites: Monteverde $\left(10^{\circ} 19^{\prime} \mathrm{N}, 84^{\circ} 47^{\prime} \mathrm{W} ; 1,550 \mathrm{~m}\right.$ asl $)$ in the Tilarán Mountain Range; Poás Volcano $\left(10^{\circ} 11^{\prime} \mathrm{N}, 84^{\circ} 13^{\prime} \mathrm{W} ; 2,700 \mathrm{~m}\right.$ asl), Irazú Volcano $\left(09^{\circ} 59^{\prime} \mathrm{N}, 83^{\circ} 52^{\prime} \mathrm{W} ; 3,200 \mathrm{~m}\right.$ asl), and Barva Volcano $\left(10^{\circ} 08^{\prime} \mathrm{N}, 84^{\circ} 06^{\prime} \mathrm{W} ; 2,800 \mathrm{~m}\right.$ asl) in the Central Mountain Range; and Macizo Cerro de la Muerte $\left(09^{\circ} 33^{\prime} \mathrm{N}, 83^{\circ} 43^{\prime} \mathrm{W}\right.$; $3,100 \mathrm{~m}$ asl) in the Talamanca Mountain Range. Mountain ranges and field sites within mountain ranges are separated by geographic discontinuities of different magnitude such as watersheds and mountain passes (Fig. 1).

We censused birds 4-7 times in each of the sites to account for possible fluctuations due to climatic conditions. Censuses started at $0545 \mathrm{hrs}$ and all individuals heard and seen within $25 \mathrm{~m}$ of each side of the transect were recorded. Length of transects varied from 1.9 to $3.0 \mathrm{~km}$ among sites. Thus, abundance was expressed as individuals $/ \mathrm{km}$ to allow comparison among sites. We used abundance categories based on mean values across censuses for each site. Categories were defined as very common $(>20$ individuals observed/census), common (10-19 individuals/ census), uncommon (5-9 individuals/census), and rare ( $<5$ individuals/census). We calculated the area of the potential available habitat for Sootycapped Bush Tanagers on each mountain range using Geographical Information Software (ArcView GIS 3.3) on a digital elevation map of Costa Rica (1:200,000; Lambert conformal con- 
ical projection) (Fig. 1). This area was estimated from the lower limit of the altitudinal distribution of Sooty-capped Bush Tanager to the summit of the mountains in each mountain range.

We set 5-8 mist nets (12 m long) during each visit to a study site. The following measurements were taken for each individual captured: body mass, length of the bill from distal end of nares to the bill tip, width of the bill at front of nares, length of the culmen from the front of the skull to the bill tip, tarsus from the tibiotarsus joint to the distal end of the tarsometatarsus, flattened wing cord, and tail length. These morphological traits were chosen as they are expected to respond adaptively to ecological differences in habitat (Grant 1986, Price and Boag 1987) and were taken by the same person (GB). Birds were banded (plastic bands) to avoid re-measuring the same individuals. Morphological data were first analyzed using a stepwise (forward) discriminant function analysis (DFA). This option excludes those variables that have no further effect in explaining the between-population variance. We used a MANOVA on those variables included in the DFA. Statistical analyses were performed in Statistica Version 6.0 (StatSoft Inc., Tulsa, OK, USA).

Laboratory Procedures.-DNA was extracted from liver tissue of 56 individuals that had been obtained in previous years and maintained in the tissue collection at the Zoology Museum at the University of Costa Rica. We collected blood samples from five additional individuals for a total of 61 individuals (14 from Cerro de la Muerte, 9 from Irazú Volcano, 18 from Barva Volcano, 11 from Poás Volcano, and 9 from Monteverde). Tissue samples were preserved in $95 \%$ alcohol and stored at $-20^{\circ} \mathrm{C}$ until DNA extraction. DNA was extracted using a commercial extraction kit for animal tissue and blood (Promega, Madison, WI, USA) following the specifications provided by the manufacturer.

Genotypes of the 61 individuals were obtained using three microsatellite loci (Esc $\mu 1$, Esc $\mu 4$, and Escu6; Hanotte et al. 1994) isolated from the related species Emberiza schoeniclus (Yuri and Mindell 2002). The three microsatellites used were the most polymorphic for E. schoeniclus. Microsatellites were amplified using an Eppendorf Mastercycler thermocycler in a volume of $25 \mu \mathrm{l}(12.5 \mu \mathrm{l}$ of PCR Master Mix $2 \times$ PROMEGA, $2.5 \mu \mathrm{l}[10 \mu \mathrm{m}]$ of each primer, $5 \mu \mathrm{l}$ of DNA, and $2.5 \mu \mathrm{l} \mathrm{H}_{2} \mathrm{O}$ ) following protocols for each locus as described in Hanotte et al. (1994). Genotypes were obtained using an automatic sequencer (ABI Prism 310, Applied Biosystems, Palo Alto, CA, USA). Alleles were sized using the program GENOTYPER (3.7NT, Applied Biosystems, Palo Alto, CA, USA).

We counted the number of alleles per locus and calculated their frequencies in each population. We tested deviations of these alleles from HardyWeinberg equilibrium with a Chi-square test using the program GENALEX 6 (Peakall and Smouse 2006); sequential Bonferroni correction was applied due to performance of multiple simultaneous tests (Rice 1989). The observed (Ho) and expected (He) heterozygosity per locus in each population were calculated using program ARLEQUÍN Version 3.1 (Schneider et al. 2000, Excoffier et al. 2005). An analysis of molecular variance (AMOVA) was used to assess population structure with 30,000 permutations to infer significance of $F_{\text {st }}$ values (Weir and Cockerham 1984). AMOVA calculations were conducted using ARLEQUÍN Version 3.1 (http://cmpg. unibe.ch/software/arlequin3). We also checked all loci for the presence of null alleles (Chakraborty et al. 1992, Brookfield 1996) using MicroChecker Version 2.2.3 (University of Hull, Hull, UK; http://www.microchecker.hull.ac.uk/; van Oosterhout et al. 2004). All loci were tested based on a dinucleotide repeat motif and 1,000 permutations.

We further examined population structure and admixture using a model-based clustering method as implemented in the Bayesian clustering program STRUCTURE (Pritchard et al. 2000, Falush et al. 2003). We inferred population structure using a model which allowed for admixture and correlated allele frequencies. Each Monte Carlo Markov Chain employed to infer population structure was based on 1,000,000 iterations and a burn-in of 100,000. Multiple runs were conducted changing the number of putative populations $(\mathrm{K})$ between one and five. At least three independent runs were assessed to estimate the likelihood of the data and the posterior probabilities for each fixed number of populations (K).

We calculated genetic distances between populations using two parameters: Nei's $(D m)$ genetic distance and $F_{\text {st }}$ (Nei 1987, Nei and Kumar 2000). We correlated genetic distances ( $F_{\text {st }}$ values) with geographic distances $(\mathrm{km})$ using a Mantel test and examined whether area of habitat available for 
each population correlated with allele number and/or genetic distance $(D m)$ using ARLEQUÍN.

\section{RESULTS}

Null Alleles.-We found no evidence of null alleles on the first two loci (Esc $\mu 1$ and Esc $\mu 4)$ with combined probability for all cases of $P>$ 0.05. The third locus (Esc $\mu 6)$ showed a significant homozygote excess congruent with the presence of null alleles $(P<0.001)$. No evidence of scoring errors or allele drop-out was found for any loci. Observed allele frequencies for the third locus only deviated slightly (at 0.01 level) from frequencies estimated considering the presence of null alleles. AMOVA analyses were performed twice using only Esc $\mu 1$ and Esc $\mu 4$ loci, and using all three loci. Results were similar with small deviations at the 0.001 level. Thus, we used all three loci for further analysis.

Genetic Variation and Population Structure.Microsatellite loci were highly polymorphic within each population relative to the number of genotyped individuals (Table 1). Allele number in any locus ranged from seven to 18 across populations. The Barva Volcano population had the highest average number ( \pm SD) of alleles (9.33 \pm 0.66), while Monteverde had the lowest (5.67 \pm 0.66; Table 2). All populations had unique alleles, although number of these alleles varied across populations: four in Barva, three in Cerro de la Muerte and Monteverde, and two in Irazú and Poás populations (Table 1). Frequency of the allele Esc $\mu 6$ significantly deviated from Hardy-Weinberg expectations (lower observed values than expected) in Cerro de la Muerte $\left(X^{2}\right.$ $=64.36, \mathrm{df}=36, P=0.003)$, Barva Volcano $\left(X^{2}\right.$ $=113.56, \mathrm{df}=45, P<0.0001)$, and Monteverde $\left(X^{2}=48.0, \mathrm{df}=21, P=0.001\right)$.

All populations had high levels of genetic diversity based on observed heterozygosity, which did not deviate significantly from expected heterozygosity in all populations (Table 2). Genetic variation was higher within populations than between populations; $98 \%$ of the total variance was distributed within populations and only $2 \%$ among populations $\left(\varphi_{s t}=0.0153 ; P>0.17\right)$. These results are consistent with high levels of gene flow among populations. Genetic structure estimates among populations were similar if the third locus was removed due to the likelihood of null alleles $\left(\varphi_{s t}=0.0154 ; P>0.18\right)$. Similarly, analyses using STRUCTURE showed no evidence of significant population structure. The highest likelihood was obtained when the number of populations was set to one $(\mathrm{K}=1)$, which suggests complete admixture.

Pairwise $F_{\text {st }}$ values ranged from 0.04 between Barva and Poás to 0.09 between Irazú and Monteverde (Table 3). $F_{\text {st }}$ values and geographic distances were not significantly correlated (Mantel test, $r=0.49, P=0.09$ ); similar results were obtained using a simple linear correlation.

We did not detect any genotypic difference between three individuals of the grayish-green morph and six individuals of the darker morph in the Irazú population. Both color morphs shared some genotypes.

Morphological Variation.-We captured 72 individual Sooty-capped Bush Tanagers; 24 at Cerro de la Muerte (Estación Biológica Cerro de la Muerte), 11 at Irazú, 18 at Barva, 10 at Poás, and nine at Monteverde. Culmen length, wing cord, tail length, bill width, and body mass differed among populations (DFA: $F_{20,168}=$ 2.63, $P=0.0003)$. The Monteverde population had the shortest culmen and wing length and the widest bill; the Irazú population had the longest tail (Wilks' lambda $=0.64$, df $=16 / 174, P=$ 0.04; Table 4).

Population Size and Habitat Area.-Sootycapped Bush Tanagers were very common $(>20$ individuals/census, corrected by distance) at Barva and Poás, and common at other sites (1019 individuals/census). The highland habitat available for Sooty-capped Bush Tanagers decreased from the Talamanca Mountain Range to the Tilarán Mountain Range. The Talamanca Mountain Range has $80.8 \%$ of the total natural highland habitat potentially available for this species (293,135 ha), while the Central Mountain Range has $17 \%$ and the Tilarán Mountain Range has $3 \%$. Area of available habitat was not correlated with number of alleles $(r=0.53, n=$ $5, P=0.16)$ nor with genetic distance (Nei's) $(r$ $=0.62, n=5, P=0.11)$ in Sooty-capped Bush Tanager populations.

\section{DISCUSSION}

All populations of the Sooty-capped Bush Tanager had high genetic variation as indicated by genetic diversity indices and number of alleles per locus. The genetic diversity within populations of Sooty-capped Bush Tanager is unexpectedly high for an endemic species with a small and naturally fragmented geographical distribution (Tables 1, 2). Within-population genetic variation 

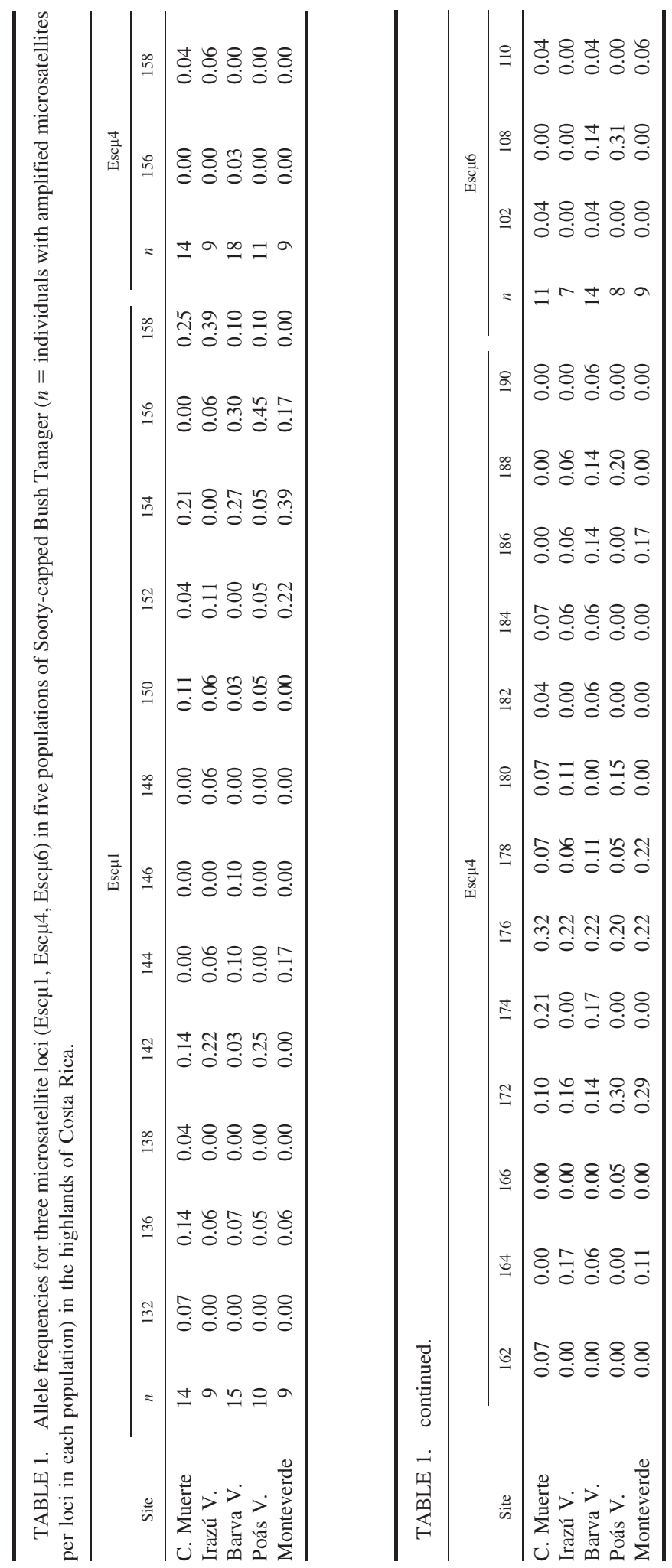

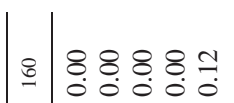

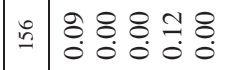

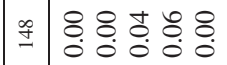

어

$=\because r \pm r$

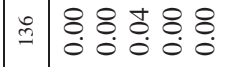

I

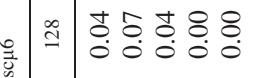

跑

苗

I

I

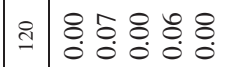

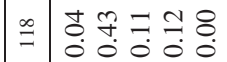

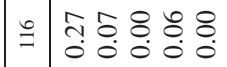

$\pm \quad 8: 80$.

$\cong 8.8: 8.8 \%$

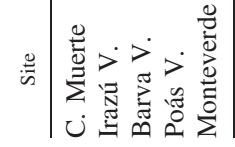




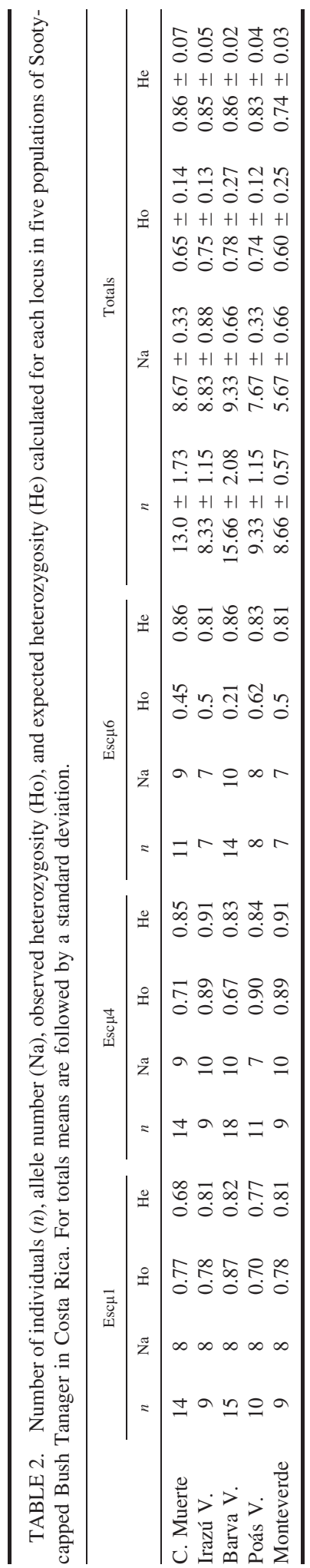

is expected to be small compared to betweenpopulation variation in species with small ranges and fragmented distributions, mainly due to genetic drift or founder effects and small effective population size (Peterson et al. 1992, Avise 1994). The absence of genetic structure among populations of Sooty-capped Bush Tanagers indicates gene flow may be relatively high among populations, counteracting the effects of genetic drift, small effective population size, and local adaptation even in small populations (Avise 1994). However, time since population isolation may have also affected the near absence of genetic structure in this endemic species. Populations are expected to retain most of their original genetic composition (Templeton et al. 1995) if isolation is relatively recent, as it has been hypothesized for Costa Rican highland endemic species (Stiles 1983, Barrantes and Sánchez 2000, Weir 2006, Barrantes 2009),

There were some genetic and morphological differences across populations of the Sootycapped Bush Tanager. For example, the presence of unique alleles in each population indicates that processes of random drift, inbreeding, and perhaps local adaptation are causing the genetic differences among populations. Genetic difference between populations ( $F_{\text {st }}$ values) tend to increase with geographic distance $(P=0.09)$ suggesting some limitation in dispersal. However, gene flow among populations likely dilutes the effect of these processes. Schwartz et al. (1986) indicated that gene flow rates as low as one migrant per generation are generally effective to prevent loss of genetic variation from habitat fragmentation.

Morphology differed among some Sootycapped Bush Tanager populations. Morphological differences may be caused by different abiotic and biotic pressures operating on different populations. For example, the habitat of the Sootycapped Bush Tanager in Monteverde is exposed to relatively intense trade winds year round (Clark et al. 2000). Birds in this population had shorter wings (Table 4), which are more efficient at maneuvering under strong wind conditions (Pennycuick 1968, Thomas 1996, Marguerie et al. 2007). There is no clear explanation for differences in other morphological traits (e.g., culmen, tail, and bill width), as fruit species and habitat structure appear similar across localities (Barrantes and Loiselle 2002). Morphological divergence between populations has been reported for other endemic birds in the highlands of Costa Rica 
TABLE 3. Geographic distance $(\mathrm{km})$ above diagonal and $F_{\text {st }}$ values (below the diagonal) between five populations of Sooty-capped Bush Tanager in the highlands of Costa Rica.

\begin{tabular}{lccccc}
\hline \multicolumn{1}{c}{ Site } & C. Muerte & Irazú V. & Barva V. & Poás V. & Monteverde \\
\hline C. Muerte & - & 47 & 74 & 91 & 142 \\
Irazú V. & 0.042 & - & 34 & 48 & 103 \\
Barva V. & 0.047 & 0.063 & - & 15 & 71 \\
Poás V. & 0.063 & 0.060 & 0.040 & - & 55 \\
Monteverde & 0.053 & 0.090 & 0.059 & 0.078 & - \\
\hline
\end{tabular}

(Stiles 1983, 1985; Barrantes and Sánchez 2000), indicating rapid morphological divergence among populations, if recent population fragmentation is assumed (Stiles 1983, 1985; Barrantes and Sánchez 2000; Barrantes 2009). The lack of concordance between morphology and genetics in this study is possibly caused, at least in part, by the intrinsic characteristics of the microsatellites. These genetic markers are neutral (or nearly so) whereas morphological traits are frequently under strong selective pressures (Zwartjes 2003, Santiago-Alarcon et al. 2006), and changes in traits presumed to be under selection often do not correlate with variation of microsatellites (Phillimore et al. 2008) or mitochondrial DNA markers (McCormack et al. 2008, Weir et al. 2008).

We found no genetic differences between the two color morphs in the Irazú population. Genotypes vary among individuals of each morph and some genotypes are shared with individuals of the other morph. Our findings support the hypothesis of Carriker (1910) and Johnson and Brush (1972), who suggested that differences in coloration reflect two morphs of the same species. We found individuals of the grayish-green morph vary greatly in coloration. All grayish-green birds also had yellow nasal tufts, and one had one yellow secondary feather in its right wing (GB, unpubl. data). Evidence that helps explain this polymorphism is elusive. Birds of both morphs use the same habitat, forage together, and apparently mate with each other (Johnson and Brush 1972; GB, unpubl. data). Johnson and Brush (1972) suggested that brighter coloration of grayish-green individuals is favored during periods of high volcanic activity when ash in the atmosphere reduces visibility. However, information on abundance of each morph during high and low volcanic activity periods is needed to test this hypothesis. This polymorphism may have evolved recently by assortative mating with some reproductive barriers, but its detection only would be possible with detailed genetic and behavior studies (Yeh 2004, McGlothlin et al. 2005).

The geographic distribution of the Sootycapped Bush Tanager on only three mountain ranges, the number of naturally isolated populations $(n=5)$, as well as the low number of alleles analyzed $(n=3)$ imposed some restrictions on analyses and limited the statistical power of some results. For example, the low number of microsatellite loci limited use of more detailed analyses to quantify gene flow. Similarly, lack of significant correlation between geographic and pairwise genetic differences was likely caused by the small number of isolated populations. In addition, we did not survey Sooty-capped Bush Tanagers in western Panamá where the Fortuna Mountain Pass may limit bird movement across this geographic discontinuity, affecting the scope of our findings.

The geographic discontinuities that separate populations of Sooty-capped Bush Tanagers as well as the area of available habitat appear to have had little effect in shaping the genetic structure of this endemic species. The presence of divergent morphologies and color morphs in some populations and unique alleles in all populations of Sooty-capped Bush Tanager suggest some isolation and/or local adaptation of populations (Stiles 1983, 1985; Barrantes and Sánchez 2000). This

TABLE 4. Morphological traits (mean \pm SD) for five populations of Sooty-capped Bush Tanager in the highlands of Costa Rica. (Length $=\mathrm{mm}$, body mass $=\mathrm{g}$ ).

\begin{tabular}{lrrrrccc}
\hline & \multicolumn{7}{c}{ Morphology traits } \\
\cline { 2 - 8 } \multicolumn{1}{c}{ Site } & \multicolumn{1}{c}{ Culmen length } & \multicolumn{1}{c}{ Wing cord } & \multicolumn{1}{c}{ Tail length } & \multicolumn{1}{c}{ Tarsus length } & \multicolumn{1}{c}{ Bill length } & \multicolumn{1}{c}{ Bill width } & Mass \\
\hline C. Muerte & $15.35 \pm 1.11$ & $71.6 \pm 2.91$ & $64.0 \pm 4.65$ & $23.85 \pm 0.76$ & $6.38 \pm 0.32$ & $6.38 \pm 0.32$ & $19.90 \pm 1.44$ \\
Irazú V. & $16.0 \pm 0.84$ & $70.31 \pm 2.63$ & $55.0 \pm 2.20$ & $24.21 \pm 0.88$ & $6.41 \pm 0.28$ & $6.42 \pm 0.28$ & $19.87 \pm 0.87$ \\
Barva V. & $15.22 \pm 0.91$ & $69.7 \pm 2.70$ & $61.66 \pm 3.52$ & $23.70 \pm 0.76$ & $6.40 \pm 0.48$ & $6.40 \pm 0.48$ & $20.28 \pm 1.16$ \\
Poás V. & $15.88 \pm 1.15$ & $69.5 \pm 2.51$ & $61.93 \pm 2.09$ & $23.68 \pm 0.90$ & $6.36 \pm 0.38$ & $6.36 \pm 0.38$ & $20.37 \pm 2.57$ \\
Monteverde & $13.58 \pm 2.71$ & $68.1 \pm 4.35$ & $55.57 \pm 3.69$ & $23.14 \pm 1.15$ & $6.43 \pm 0.77$ & $6.43 \pm 0.77$ & $17.65 \pm 1.67$ \\
\hline
\end{tabular}


system of geographically isolated populations deserves special conservation attention, because it presents a unique opportunity to further study incipient causes of population divergence in an area of high endemism.

\section{ACKNOWLEDGMENTS}

We thank Johel Chaves, John McCormack, Jason Weir, and C. E. Braun for helpful comments that largely improved the manuscript. We also thank César Sánchez for helping with field work and Federico Valverde for logistic support. Financial support was provided by the Consejo Nacional para Investigaciones Científicas y Tecnológicas (CONICIT), the Asociación Ornitológica de Costa Rica, and the Vicerrectoría de Investigación, Universidad de Costa Rica.

\section{LITERATURE CITED}

AvisE, J. C. 1994. Molecular markers, natural history and evolution. Chapman and Hall Press, New York, USA.

BARRANTES, G. 2000. Ecology and evolution of Phainoptila melanoxantha (Bombycilidae, Aves) in the highlands of Costa Rica and western Panama. Dissertation. University of Missouri-St. Louis, USA.

BARRANTES, G. 2009. The role of historical and local factors in determining species composition of the highland avifauna of Costa Rica and western Panamá. Revista Biología Tropical 57 (Supplement 1): In press.

BARRANTES, G. AND J. SÁNCHEZ. 2000. A new subspecies of Black and Yellow Silky Flycatcher, Phainoptila melanoxantha (Bombycilidae, Aves), from Costa Rica. Bulletin of the British Ornithological Club 120:40-46.

BARRANTES, G. AND B. A. LoISElLE. 2002. Reproduction, habitat use and natural history of the Black-andYellow Silky Flycatcher (Phainoptila melanoxantha), an endemic bird of western Panama-Costa Rica highlands. Ornitología Neotropical 13:121-136.

BrooKfield, J. F. Y. 1996. A simple new method for estimating null allele frequency from heterozygote deficiency. Molecular Ecology 5:453-455.

CARRIKER JR., M. A. 1910. An annotated list of birds of Costa Rica, including Cocos Island. Annals of the Carnegie Museum 6:314-915.

Chakraborty, R., M. De Andrade, S. P. Daiger, and B. BuDOWLE. 1992. Apparent heterozygote deficiencies observed in DNA typing data and their implications in forensic applications. Annals of Human Genetics 56:45-47.

Clark, K. L., R. O. LAwton, AND P. R. Butler. 2000. The physical environment of Monteverde. Pages 10-25 in Monteverde: ecology and conservation of a tropical cloud forest (N. M. Nadkarni and N. T. Wheelwright, Editors). University of Chicago Press, Chicago, Illinois, USA.

Eisenmann, E. 1955. The species of Middle American birds. Transactions of the Linnean Society of New York 7:1-128.

Excoffier, L., G. Laval, AND S. Schneider. 2005. ARLEQUÍN Version 3.0: an integrated software package for population genetics data analysis. Evolutionary Bioinformatics Online 1:47-50.

Falush, D., M. Stephens, and J. K. Pritchard. 2003. Inference of population structure using multilocus genotype data: linked loci and correlated allele frequencies. Genetics 164:1567-1587.

Grant, P. 1986. Ecology and evolution of Darwin's Finches. Princeton University Press, Princeton, New Jersey, USA.

Hanotte, O., C. Zanon, A. Pugh, C. Greic, A. Dixon, AND T. BURKE. 1994. Isolation and characterization of microsatellite loci in a passerine bird: the Reed Bunting Emberiza schoeniclus. Molecular Ecology 3:539-530.

JANKOWSKI, J. E. AND K. N. RABENOLD. 2007. Endemism and local rarity in birds of neotropical montane rain forest. Biological Conservation 138:453-463.

Johnson, N. K. AND A. H. BRUSh. 1972. Analysis of polymorphism in the Sooty-capped Bush Tanager. Systematic Zoology 21:245-262.

Marguerie, E., J. B. Mouret, S. Doncieux, And J. A MEYER. 2007. Artificial evolution of morphology and kinetics in a flapping-wing mini-UAV. Bioinspiration and Biomimetics 2:65-82.

McCormack, J. E., A. T. Peterson, E. Bonaccorso, AND T. B. Smith. 2008. Speciation in the highland of Mexico: genetic and phenotypic divergence in the Mexican Jay (Aphelocoma ultramarina). Molecular Ecology 12:423-434.

McGlothlin, J. W., P. G. Parker, V. Nolan JR., AND E. D. KetTerson. 2005. Correlational selection leads to genetic integration of body size and an attractive plumage trait in Dark-eyed Juncos. Evolution 59: 658_ 671.

NEI, M. 1987. Molecular evolutionary genetics. Columbia University Press, New York, USA

NeI, M. AND S. KUMAR. 2000. Molecular evolution and phylogenetics. Oxford University Press, New York, USA.

Peakall, R. and P. E. Smouse. 2006. GENAleX6: genetic analysis in Excel. Population genetic software for teaching and research. Molecular Ecology Notes 6:288-295.

PenNYCuick, C. J. 1968. A wind-tunnel study of gliding flight in the pigeon Columba livia. Journal of Experimental Biology 49:509-526.

Peterson, A. T., P. Escalante, and S. A. Navarro. 1992. Genetic variation and differentiation in Mexican populations of Common Bush-Tanagers and Chestnutcapped Brush-Finches. Condor 94:244-253.

Phillimore, A. B, I. P. F. OWens, R. A. Black, J. Chitock, T. Burke, And S. M. Clegg. 2008. Complex patterns of genetic and phenotypic divergence in an island bird and the consequences for delimiting conservation units. Molecular Ecology 17:2839-2853.

Powell, G. V. N. 1985. Sociobiology and adaptive significance of interspecific foraging flocks in the Neotropics. Ornithological Monographs 36:713-731.

Price, T. D. AND P. T. BoAg. 1987. Selection in natural populations of birds. Pages 257-287 in Avian genetics: 
a population and ecology approach (F. Cooke and P. A. Buckley, Editors). Academic Press, London, United Kingdom.

Pritchard, J. K., M. Stephens, AND P. Donnelly. 2000. Inference of population structure using multilocus genotype data. Genetics 155:945-959.

RICE, W. R. 1989. Analyzing tables of statistical tests. Evolution 43:223-225.

RidGWAY, R. 1905. New genera of Tyrannidae and Turdidae, and new forms of Tanagridae and Turdidae. Proceedings of the Biological Society of Washington $17: 211-214$

Santiago-Alarcon, D., S. M. TANKSley, AND P. G PARKER. 2006. Morphological variation and genetic structure of Galapagos Dove (Zenaida galapagoensis) populations: issues in conservation for the Galapagos bird fauna. Wilson Journal of Ornithology 118:194207.

SCHNEIDER, S., D. Rossini, AND L. ExCOFfIER. 2000. ARLEQUÍN Version 2000: a software for population genetics data analysis. Genetics and Biometry Laboratory, University of Geneva, Switzerland.

Schwartz, O. A., V. C. Bleich, And S. A. Holl. 1986. Genetics and the conservation of mountain sheep Ovis canadensis nelsoni. Conservation Biology 37:179-190.

SLuD, P. 1964. The birds of Costa Rica. Distribution and ecology. Bulletin of the American Museum of Natural History 128:1-430.

StiLes, F. G. 1983. Systematics of the southern forms of Selasphorus (Trochilidae). Auk 100:311-325.

StiLES, F. G. 1985. Geographic variation in the Fierythroated Hummingbird, Panterpe insignis. Ornithological Monographs 36:23-30.

Stiles, F. G. AND A. F. SKUTCH. 1989. A guide to the birds of Costa Rica. Cornell University Press, Ithaca, New York, USA.

Templeton, A. R., E. Routman, And C. A. Phillips. 1995.
Separating population structure from population history: a cladistic analysis of the geographical distribution of mitochondrial DNA haplotypes in Tiger Salamander, Ambystoma trigrinum. Genetics 140: 767-782.

ThOMAS, A. L. R. 1996. The flight of birds that have wings and a tail: variable geometry expands the envelope of flight performance. Journal of Theoretical Biology 183:237-245.

Van Oosterhout, C., W. F. Hutchinson, D. P. M. Wills, AND P. SHIPLEY. 2004. Micro-Checker: software for identifying and correcting genotyping errors in microsatellite data. Molecular Ecology Notes 4:535538.

WeIR, B. S. AND C. C. Cockerham. 1984. Estimating Fstatistics for the analysis of population structure. Evolution 38:1358-1370.

WEIR, J. T. 2006. Divergent timing and patterns of species accumulation in lowland and highland neotropical birds. Evolution 60:845-855.

Weir, J. T., E. Birmingham, M. J. MiLler, J. KlickA, AND M. A. GonZÁLez. 2008. Phylogeography of a morphologically diverse neotropical montane species, the Common Bush-Tanager (Chlorospingus ophthalmicus). Molecular Phylogenetics and Evolution 47:650-664.

YEH, P. J. 2004. Rapid evolution of a sexually selected trait following population establishment in a novel habitat. Evolution 58: 166-174.

YURI, T. AND D. P. MindelL. 2002. Molecular phylogenetic analysis of Fringillidae, New World nine-primaried oscines. (Aves: Passeriformes). Molecular Phylogenetics and Evolution 23:229-243.

ZWARTJES, P. W. 2003. Genetic variability in migratory and endemic island songbirds (genus Vireo): a comparative assessment using molecular and morphological traits. Conservation Genetics 4:749-758. 